Näkökulma

Prologi - puheviestinnän

vuosikirja 2017

$42-49$

\title{
Työyhteisösovittelu vuorovaikutuksen kehittämisen työkaluna
}

\author{
Pia Lappalainen \\ Lehtori, TkT, FM \\ Aalto-yliopisto, Kielikeskus \\ pia.lappalainen@aalto.fi
}

\section{Tiivistelmä}

Taloudellisesti haastavina aikoina teollisuudessa on totuttu etsimään tuottavuuden kasvua kovista HR-toimenpiteistä, kuten henkilöstö- ja koulutusleikkauksista. Pehmeämmät keinot ovat jääneet huomiotta, vaikka henkilöstötuottavuuteen vaikuttavia laatutekijöitä voitaisiin luoda vähäisin kustannuksin esimerkiksi johtamisen ja viestintäkulttuurin avulla. Panostukset organisaation vuorovaikutukseen edistävät psyykkisen ja sosiaalisen pääoman rakentumista, ja työniloa lisätessään rakentava kanssakäyminen edistää työtehoa. Merkittävä on myös dialogisen organisaatiokulttuurin rooli eripuran ehkäisemisessä. Pitkittyessään työpaikan konfliktit syövät tehollista työaikaa ja eskaloituneina aiheuttavat työpahoinvointia, joka sairauspoissaolojen, alentuneen työkyvyn ja ennenaikaisen eläköitymisen kautta kerryttää kustannusvaikutuksia. Toimivalla vuorovaikutuskulttuurilla on täten sekä voimavaroja moninkertaistava että kustannuksia minimoiva vaikutus.

Tässä näkökulma-artikkelissa tarkastellaan työyhteisösovittelua työhyvinvointia syövien konfliktien ratkomiskeinona. Artikkelissa kuvataan lyhyesti restoratiivisen työyhteisösovittelun periaatteet ja prosessin vaiheet. Toiseksi artikkelissa kartoitetaan aiemman kirjallisuuden pohjalta restoratiivisen sovittelun hyötyjä työyhteisöjen dynamiikan ja vuorovaikutuksen kehittämiselle ja löydöksiä havainnollistetaan työyhteisösovitteluun osallistuneiden ihmisten kokemuksilla. Tarkoituksena on muodostaa työyhteisösovittelusta kokonaiskuva arjen vuorovaikutuskonflikteja ratkaisevana ja toisaalta uusia ihmissuhdeongelmia ehkäisevänä metodina.

ASIASANAT: ihmissuhdekonfliktit, restoratiivinen työyhteisösovittelu, vuorovaikutus 


\section{Johdanto}

Talouden haasteet ovat sysänneet organisaatiot etsimään tuottavuuden kasvua työajan lisäämisestä ja kovista HR-toimenpiteistä, kuten henkilöstövähennyksistä ja kulukurista. Työn käsitteen ja toimintaympäristön muutosten myötä (Rouhiainen 2005) laajempi yhteiskunnallinen huomio on kuitenkin kääntymässä työelämän laatutekijöihin, jotka henkiseen kuormitukseen vaikuttaen ovat yhteydessä henkilöstötuottavuuteen (Kesti \& Syväjärvi 2012).

Verrattuna esimerkiksi teknisiin prosesseja sujuvoittaviin innovaatioihin, työn tekemisen laatua ja työhyvinvointia nostattavat inkrementaaliset uudennokset aiheuttavat vähemmän kustannuksia. Näitä pehmeitä tekijöitä voidaan luoda hyvän johtamisen, sekä viisaiden henkilöstöpoliittisten valintojen, tarkoituksenmukaisten HR-prosessien ja dialogisen viestintäkulttuurin avulla. Kuuntelemisen ja empatian sekä hyvinvoinnin välillä oleva yhteys on tunnistettu (Laajalahti 2016) ja vuorovaikutuksen nähdään kiistattomasti palvelevan työhyvinvointia. Parhaimmillaan työpaikan tunnelma ja dynamiikka edistävät työnimua, sitoutumista ja työtehoa, alasta riippumatta (Matilainen 2014; Lappalainen 2015; Vanhala 2014). Vastaavasti eripuran aiheuttama mielipaha on hälyttävä haitta: eskaloituneina ristiriidat aiheuttavat psyykkistä ja fyysistä pahoinvointia (Rainivaara \& Karhunen 2006). Sairauspoissaolojen, alentuneen työkyvyn ja ennenaikaisen eläköitymisen kautta työpahoinvointi kerryttää kustannusvaikutuksia ja syö tuottavuutta (De Dreu \& Weingart 2003).

Näiden tilastollisten löydösten seurauksena ihmissuhdeongelmat ovat viime vuosina nousseet työelämätutkimuksen tarkastelun keskiöön merkittävimpänä henkisen kuormituksen aiheuttajana (Kessler ym. 2013). Tietyssä mää- rin työpaikan konfliktit tarjoavat potentiaalia oppiville ja uutta luoville organisaatioille (De Dreu \& Van Vianen 2001), mutta soraäänien vakiintuessa ristiriidoiksi menetetyn työpanoksen kustannukset syövät niitä hyötyjä, joita perinteisillä tuottavuuden edistämistoimenpiteillä tavoitellaan (Okhuysen ym. 2013).

Ratkaisuna työpaikan kitkaan arvontuottokykyä on yhä useammissa organisaatioissa ryhdytty rakentamaan pureutumalla organisaatiokonfliktien syihin ja ristiriitojen ratkaisemiseen. Tehokkaaksi ulkopuoliseksi interventioksi on todettu Prologos ry:n Vuoden 2016 Vuorovaikutustekona palkitsema Pehrmanin restorativinen työyhteisösovitteluprosessi. Vuorovaikutushaasteiden juurisyihin paneutuvana prosessina tämä työkalu antaa yksilölle mahdollisuuden tarkastella toimintaansa kanssaihmisten silmin, tulematta tuomituksi tai rangaistuksi. Sovittelu varmistaa ajan ja paikan kohtaamiselle, joka lisää osapuolten itsetuntemusta, avaa silmät väärinymmärryksille ja mahdollistaa aidon anteeksiannon. (Pehrman \& Poikela 2015.)

Työyhteisösovittelu on fasilitatiivinen menetelmä, joka säilyttää osapuolilla ongelman omistajuuden ja auttaa heidät itse löytämään sovun avaimet rohkaisten yksilöt henkilökohtaiseen kasvuun ja työyhteisöt kestävään muutokseen. Sovitteluprosessin läpikäyneet huomaavat usein viestintäkulttuurissaan muutoksen mekanistisesta tiedonsiirrosta sosiaalisten suhteiden syvenemiseen ja voimaannuttavaan jakamiseen. Dialogisuuden myötä vuorovaikutuksesta tulee resurssi (Juholin 2013), joka edesauttaa tietopääoman jakamista ja kumuloitumista - se on siten myös tietojohtamisen työkalu (Rouhiainen 2005).

Tässä näkökulma-artikkelissa on kaksi tavoitetta. Kuvaan restoratiivisen työyhteisösovittelun periaatteet ja prosessin vaiheet. Toiseksi kar- 
toitan kirjallisuuden pohjalta prosessin hyötyjä työyhteisöjen dynamiikan kehittämiselle ja havainnollistan pohdintaa työyhteisösovitteluun osallistuneiden ihmisten kuvauksilla siitä, miten prosessi vaikutti heihin yksilöinä.

\section{Vuorovaikutus työhyvinvoinnin perustana}

Yleisesti organisaatioiden toiminnan nähdään yhä voimakkaammin rakentuvan vuorovaikutukselle (Lappalainen 2015; Rouhiainen 2005;). Vuorovaikutuksen laatu ja määrä vaikuttavat keskeisesti kokemukseen työhyvinvoinnista ja vastaavasti puutteet lähikollegoiden välisessä viestinnässä nähdään työhyvinvointia vakavasti rapauttavana stressitekijänä (Avey ym. 2011). Siinä missä rakentava dialogi lisää tarmokkuutta, uppoutumista ja omistautumista, ongelmat työpaikan ihmissuhteissa aiheuttavat yhteistyön takkuamista ja konflikteja (Pennanen 2015), sekä lopulta syövät tuottavuutta (Kessler ym. 2013).

Työyhteisöjen monimuotoistuminen haastaa yksilöiden viestintätaidot ja muuntaa aivotyön yhtä selkeämmin tunnetyöksi (Fineman 2003). Positiivinen psykologia on osoittanut positiivisten tunteiden ja työhyvinvoinnin yhteyden kognitiivisten resurssien kasvuun, suoriutumistason nousuun ja parempaan fyysiseen terveyteen (Fredrickson \& Levenson 1998; Fredrickson \& Branegan 2005).

Konflikteilla puolestaan on kauaskantoisia taloudellisia, sosiaalisia ja emotiivisia seurauksia (Kessler ym. 2013.) Onkin hälyttävää, että sosio-emotiivisten stressitekijöiden määrän nähdään olevan kasvussa. Tätä on selitetty tiimien diversiteetillä ja siihen liittyvällä arvojärjestelmien moninaisuudella, joka voi altistaa työyhteisöt konflikteille. Toinen selittävä tekijä on vuorovaikutuksen lisääntyminen.
Tämän päivän aivotyössä tiimityöskentelystä on tullut työyhteisöjen normi: jopa $60 \%$ työntekijöistä kuuluu vähintään yhteen tiimiin (Horila \& Valo 2016). Vuorovaikutussuhteiden monimuotoistuessa lisääntyvät työyhteisön jännitteetkin (De Dreu \& Weingart 2003), mikä puolestaan kasvattaa vaatimuksia työntekijöiden sivistynyttä ja ennakoitavaa käyttäytymistä kohtaan (Andersson \& Pearson 1999).

Valitettavan usein organisaation harmonia kuitenkin rikkoutuu tavalla, joka haittaa työn sujumista ja aiheuttaa psykososiaalista kuormitusta, jopa työuupumusta. Vaikka konfliktit itsessään ovat vain harvoin yksinomaan vahingollisia, suurta haittaa voi aiheuttaa tapa, jolla niihin suhtaudutaan, puututaan tai ollaan puuttumatta (Gibson \& Callister 2010). Tällöin ristiriidan mainingeilla on taipumus levitä, jolloin se alkaa viedä huomiota ja syödä työaikaa ja voimavaroja yhä isommalta työntekijäjoukolta. Alentuneen tuottavuuden lisäksi puuttumattomuus värittää yksilöiden kokemusta organisaation ja johtamisen oikeudenmukaisuudesta ja ennustaa työn sujumista tulevaisuudessakin (Kruger \& Brodbeck 2014). Olennaista ei ole se mistä riidellään, vaan se, miten ongelmat ratkotaan (DeChurch 2001).

\section{Restoratiivinen työyhteisösovittelu}

Suomessa jo yli tuhannen koulutetun työyhteisösovittelijan voimin harjoitettu työyhteisösovittelu nojaa restoratiivisen oikeuden traditioon ja toteutuu puolueettoman osapuolen interventiona. Tarkoituksena ei ole niin sanotusti tuomita syyllisiä tai rangaista väärintekijöitä, vaan eheyttää riidan osapuolten psyyke, korjata rikki mennyt vuorovaikutuskulttuuri, palauttaa työntekijän henkiset resurssit ja saattaa yhteen toisistaan erkaantuneet intressit. Tämä prosessi antaa osapuolille mahdollisuuden aitoon 
kohtaamiseen ja luottamuksen rakentamiseen. (Pehrman \& Poikela 2015.)

Restoratiivinen sovittelu edustaa välitystoiminnan ei-direktiivistä ääripäätä, jossa sovittelija on neutraali ja puolueeton fasilitaattori. Toisesta ääripäästä löytyy direktiivinen koulukunta, jossa sovittelijan vahvalla evaluatiivisella otteella on tärkeä rooli määritettäessä syyllistä tai väärintekijää sekä rangaistusta rikkomuksesta (Wall \& Kessler 2012.) Sovittelumenetelmän valinta kuvastaa metodologisia preferenssejä ja näkyy myös sovittelijan toimintatyylissä. Direktiivinen sovittelija kysyy suljettuja kysymyksiä, tekee johtopäätöksiä ja esittelee ratkaisuvaihtoehtoja (Charkoudian 2012), kun taas restoratiivinen sovittelija esittää avoimia kysymyksiä, keskittyy kuuntelemaan, ja ihmettelemällä kuulemaansa aktivoi osapuolia ratkaisukeskeisyyteen (Pehrman 2011).

Olennaista on, että osapuolet oppivat toimimaan ristiriitatilanteissa ja etsimään ratkaisua keskenään. Mikäli ulkopuolinen toimija tarjoaisi ulospääsyn, osapuolet eivät joutuisi haastamaan itseään emotiivisesti, mikään heidän ajattelussaan ei muuttuisi, ja uuden ristiriidan ilmaantuessa he olisivat jälleen lähtötilanteessa. Sovittelija ei siis ole välittäjä tai asiamies, vaan tasapuolinen ja neutraali ulkopuolinen taho, joka varmistaa tilan ja ajan jokaisen osallistujan näkemyksille ja tuntemuksille. (Pehrman \& Poikela 2015.)

Yksinkertaisimmillaan Pehrmanin prosessi etenee kuuden (Kuvio 1) vaiheen kautta kohti sopua, sovintoa ja inhimillistä kasvua. Prosessin vaiheita voi soveltaa joustavasti ja iteratiivisesti tarpeen niin vaatiessa.

Aloitus käynnistää prosessin asianosaisen, hänen esimiehensä, kollegan tai HR:n ilmoituksesta. Infotilaisuudessa prosessi ja sovittelijat esitellään yksikölle, jossa sovittelua ollaan käynnistämässä. Erillistapaamisissa haastatellaan kaikki ne, jotka ovat konfliktin piirissä. Sovittelutapaamisessa kuullaan, miten riita on kutakin osapuolta kuormittanut, puolueettoman sovittelijan myötävaikuttaessa keskustelun avoimuuteen ja osapuolten sitoutumiseen. Tapaaminen päättyy osallistujien omaehtoiseen ratkaisuun ja sen kirjaamiseen sopimukseksi.

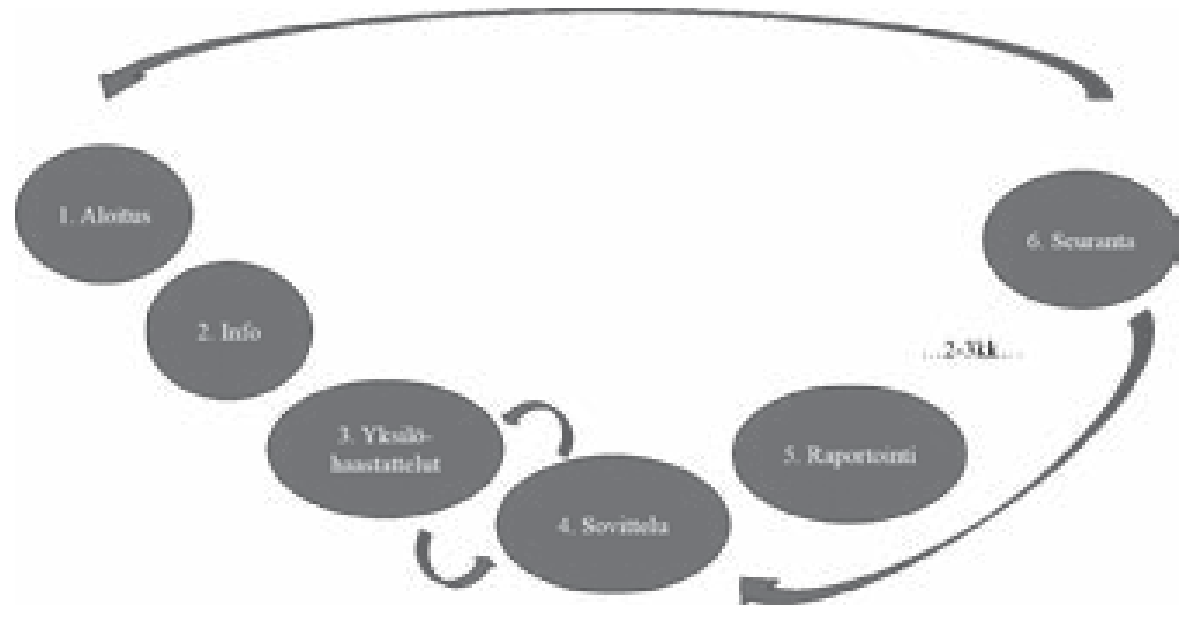

KUVIO 1 Työyhteisösovittelun vaiheet (Pehrmania 2011 mukaillen). 
Sovittelun lopputulemasta tiedotetaan niille työnantajan edustajille, joiden on työnantajavelvoitteidensa vuoksi syytä tietää prosessin etenemisestä. Seurannassa tyypillisesti 2-3 kk päästä kartoitetaan työyhteisön tilanne ja sovitaan jatkotoimista, mikäli sovittelusta ei ole ollut apua.

Aiempi kirjallisuus ja havainnollistamiseen käytetyt sovitteluun osallistuneiden kokemukset osoittavat, että juuri tämä tunnekuorman käsittely tekee prosessista osallistujille henkisesti raskaan, vaikka osallistumisen tavan ja intensiteetin kukin määritteleekin itse. Varsinkin työnantajan käyttäessä direktio-oikeuttaan sovittelun käynnistämiseksi monet kokevat "joutuvansa" sovitteluun ja protestoivat sen aiheuttamaa ajanhukkaa ja siitä seuraavaa töiden kasautumista. Alla olevat sitaatit työyhteisösovittelun osapuolilta osoittavat prosessin kuitenkin lopulta toimivan, huolimatta osapuolten asenteellisuudesta prosessin käynnistyessä.

Pyydän anteeksi aiempaa penseää suhtautumistani. Olit oikeassa - sovittelun hyödyt ymmärtää vasta kun siihen osallistuu.

Alkuun tuntui että jouduin sovitteluun. Nyt tuntuu että se olikin pääsemistä.

Monia huolestuttaa prosessin luottamuksellisuus; he pelkäävät maineensa ammatti-ihmisinä kärsivän, jos tieto osallistumisesta sovitteluun - siis konfliktiin - leviää organisaatiossa. Jotkut epäilevät sovittelijan puolueettomuutta ja ovat näkevinään merkkejä puolueellisuudesta. Yleensä nämä huolet hälvenevät infossa tai viimeistään kahdenkeskisissä keskusteluissa sovittelijan kanssa.

Sovittelu saattaa osoittautua pettymykseksi niille, jotka odottavat ulkopuolisen toimijan ratkovan ongelman ja tarjoavan valmista rat- kaisumallia. He näkevät ratkaisun pintapuolisena ja näennäisenä kompromissina, ja syyttävät epäonnistumisesta sovittelijoiden passiivista tai liian ymmärtäväistä roolia.

Siinä te sovittelijat vaan istuitte ettekä tehny mitään.

Olin alkuun kovin uupunut keskusteluista ja huolissani siitä, kuinka Y:n vääristyneitä olettamuksia pyritään rationalisoimaan ja normalisoimaan näilläkin keskusteluilla.

Vaikka osallistujien ennakkoasenteet ovat usein pessimistisiä ja prosessiin liittyviä huolenaiheita on useita, on huomionarvoista, että valtaosa osallistujista ilmaisee prosessin päätyttyä kiitollisuutta prosessia ja sovittelijoita kohtaan. Näin on usein myös niissä tapauksissa, joissa prosessin välittömään lopputulemaan ei aina oltaisikaan täysin tyytyväisiä.

Olen äärettömän kiitollinen kaikesta kokemastani ja siitä, että minulla oli hyvä ihminen rinnalla reflektoimassa omia ajatuksiani.

Opin tässä koko ajan lisää ja sovittelija oli kyllä hieno peili toiminnalleni.

Sovittelu on todella voimauttanut minua.

Sovittelu on ollut tämän vuoden kohokohtia ja olet ihan varmasti top3 ihmisten joukossa, jotka ovat vaikuttaneet minun ajatteluuni ja johtamiseen työurani aikana.

Nämä kommentit osoittavat, että sovittelussa huomio tulisikin siirtää lopputulemasta prosessiin. Syvintä oppimista tapahtuu usein vastoinkäymisten kautta, ja konfliktit tulisikin nähdä oppimisen ja kasvun mahdollistajina (Rothman 2014a). 
Myös aiemmassa kirjallisuudessa on havaittu, että työyhteisösovittelu palvelee organisaatioita kahdella tavalla riippuen ongelman juurisyistä, konfliktin tyypistä, sekä siitä, kumpaa kahdesta ääripäästä sovittelijoiden tyyli edustaa: evaluatiivista, voimakkaasti ulkopäin ohjattua ongelmanratkaisua vaiko transformatiivista fasilitointia, jossa ongelman omistajuus ja ratkaisu pysyvät osapuolten käsissä (esim. Charkoudian 2012). Edellinen, vahvasti direktiivinen toimintatapa on omiaan pyrittäessä nopeaan lopputulemaan ja tehokkaaseen ratkaisuun, kun taas jälkimmäinen on etenemiseltään ennakoimattomampi ja hitaampi, ja siinä sovittelijalla on näennäisesti passiivisempi rooli (Della Noce 2012). On kuitenkin huomattu, että osapuolet sopuun saatettuaan tämä ohjaukseltaan pidättyväisempi metodi sysää käyntiin muita, pidempikestoisia prosesseja, jotka yksilötasolla näkyvät henkilökohtaisena kasvuna ja tiimitasolla keskusteludynamiikan ja vuorovaikutusilmaston muutoksena (Wall \& Kessler 2012).

Sekä aiemman kirjallisuuden että havaintoaineiston perusteella kaikkein silmiä avaavin kokemus soviteltaville vaikuttaa olevankin reflektoinnin merkityksen oivaltaminen ja sen kautta sekä oman että toisten toiminnan ymmärtäminen. Tämä havainto herää muiden palautteista; monet eivät aiemmin ole päässeet analysoimaan toimintaansa, käyttäytymistään tai viestintäänsä turvallisessa ja kuunteluun kannustavassa ilmapiirissä. (Rothman 2014a.)

Prosessi ja sovittelijan malli kannustavat aktiiviseen kuunteluun, kun kukin osaltaan huomaa, miten merkityksellistä on saada tulla kuulluksi (Pehrman 2011). Aktiivinen kuuntelu lisää analyyttistä ja kognitiivista empatiaa, mikä tukee vastapuolen motiivien ymmärtämistä. Levollinen pysähtyminen toisten kertomusten, narratiivien, ääreen eheyttää kertojaa, lisää muiden empatiaa, antaa kuulijalle mahdollisuuden tar- kastella vaihtoehtoisia näkökulmia, ja siten laajentaa ajattelua. (Rothman 2014a.)

Tilanteen turvallisuus kannustaa myös itsetutkiskeluun, pysähtymään omien ajatusten ja tunteiden äärelle. Usein tästä aidosta ja rehellisestä tarkastelusta seuraa ymmärrys, että välitön tulkinta olikin hätiköity - sovittelu lisää ymmärrystä niin omista kuin muidenkin motiiveista. Sen tiedostaminen, että konfliktit usein alkavat väärinymmärryksestä, toimii ennaltaehkäisevästi seuraavan eripuran nostaessa päätään. (Pehrman \& Poikela 2015.)

Kiinnostavaa prosessissa on tapa, millä se kääntää osallistujien havaintomaailman muista itseen. Sen sijaan, että työntekijät keskittyisivät etsimään muiden toiminnasta pessimistisiä odotuksiaan vahvistavia todisteita, he alkavatkin reflektoida omaa käytöstään ja tunteitaan. Paremmasta itsensä tuntemisesta seuraavat hyvät päätökset saavat aikanaan tukea muiden yhä positiivisemmasta palautteesta. (Rothman 2014b.) Syntyy hyvän kehä, joka vahvistaa itseään. Yhdenkin yksilön ponnistelut rakentavamman vuorovaikutuksen eteen saavat muutkin kilvoittelemaan hyvillä teoilla.

Organisaatiotasolla nähdään, miten tunneälyn kumuloituminen, lisääntynyt myötätunto ja psykologinen läheisyys kannattelevat dialogisuutta. Aktiivinen ja lämmin vuorovaikutus on ensisijainen työhyvinvoinnin kulmakivi, mikä puolestaan nostaa aineettoman henkilöstöpääoman hyödyntämisastetta. (Kolari 2010.) Työyhteisösovittelu on siten organisaation vuorovaikutusta kehittävä työelämäinnovaatio, joka tehollista työaikaa lisäämällä vaikuttaa henkilöstötuottavuuteen (Kesti \& Syväjärvi 2015). 


\section{Lopuksi}

Tämä näkökulma-artikkeli nostaa esiin aiempien, kansainvälisten kirjallisuuskatsausten ja empiiristen tutkimusten löydökset restoratiivisen sovittelun vaikutuksista. Sovittelijan näennäisesti passiivinen rooli on yhteyksissä yksilön kasvuun ja tiimin vuorovaikutuksen kehittymiseen. Restoratiivisuuteen olennaisesti kuuluva omistajuuden periaate varmistaa, että osapuolet ottavat vastuun ratkaisusta, ja ponnistelemalla löytääkseen ulospääsyn vuorovaikutusongelmistaan he samalla kasvavat ja kehittyvät yksilöinä ja tiimeinä. Sovitteluprosessin jatkeena käynnistyvä kasvu- tai kehitysprosessi saattaa lähteä liikkeelle harmillisen epävarmasti, hatarasti ja sattumanvaraisesti, osapuolet turhauttaen. Pienet, vaiheittaiset muutokset eivät huimaa päätä tahdillaan, mutta tutkimuksellista tukea kuitenkin löytyy sille, että tämänkaltainen omaehtoinen ja sisäisistä motivaatiotekijöistä lähtevä muutos tuottaa kestävämmän tuloksen kuin ulkoa ohjattu uudistuminen.

Pidättyväinen omistajuutta tukeva fasilitointi on osallistujien ajattelua muuttava metodi, jonka jälkimainingeissa kunkin yksilön kasvu ruokkii positiivista kehitystä ympäristössä. Tällaisessa kehityksessä osapuolet kääntyvät sisäisen reflektoinnin pariin muihin suuntautuvan syyttelyn sijaan. He ovat saaneet sovittelukeskusteluista herätteen itsensä kehittämiseen ja muilta saamastaan palautteesta kimmokkeen pohtia oman vuorovaikutuksensa laatua ja merkitystä tiiminsä työskentelylle. Tämä yksittäisissä työntekijöissä itävä uudenlainen systeemiälykäs ajattelu tartuttaa muihinkin innostuksen itsensä kehittämistä kohtaan, ja pian koko työyhteisö kilvoittelee puhumalla paremmin ja enemmän. Niinkin piinallisesta ilmiöstä kuin vuorovaikutuksen ontumisesta käynnistynyt prosessi voi siis parhaimmillaan palkita yksilöt osaamisen ja persoonallisuuden kehittymisel- lä, jonka vaikutukset ulottuvat kaikille elämän alueille. Tärkeimpänä argumenttina työyhteisökontekstissa voidaan kuitenkin pitää niitä tuottavuusvaikutuksia, joita tunneälykapasiteetti, vuorovaikutteisuus ja aito halu sitoutua työyhteisöön tarjoavat lisääntyneen työhyvinvoinnin kautta.

\section{Kirjallisuus}

Andersson, L. \& Pearson, C. 1999. Tit for tat? The spiraling effect of incivility in the workplace. Academy of Management Review 24 (3), 452-471.

Avey, J., Reichard, R., Luthans, F. \& Mhatre, K. 2011. Meta-analysis of the impact of positive psychological capital on employee attitudes, behaviors and performance. Human Resource Development Quarterly 22 (2), 127-152.

Charkoudian, L. 2012. Just my style: The practical, ethical and empirical dangers of the lack of consensus about definitions of mediation styles. Negotiation and Conflict Management Research 5 (4), 367-383.

Della Noce, D. 2012. Mediator style and the question of "good" mediation: A call for theoretical development. Negotiation and Conflict Management Research 5 (4), 396-402.

De Dreu, C. \& Van Vianen, A. 2001. Managing relationship conflict and the effectiveness of teams. Journal of Organizational Behavior 22, 309-328.

De Dreu, C. \& Weingart, L. 2003. Task versus relationship conflict, team performance, and team member satisfaction: A meta-analysis. Journal of Applied Psychology 88 (4), 741-749.

DeChurch, L. 2001. Maximizing the benefits of task conflict: The role of conflict Management. International Journal of Conflict Management 12 (1), 4-22.

Deutsch, M. 1983. Conflict resolution: Theory and practice. Political Psychology 4 (3), 431-453.

Fineman, S. 2003. Understanding emotion at work. London: Sage.

Fredrickson, B. \& Levenson, R. 1998. Positive emotions speed recovery from the cardiovascular sequelae of negative emotions. Cognition and Emotion 12 (2), 191-220. 
Fredrickson, B. \& Branigan, C. 2005. Positive emotions broaden the scope of attention and thought-action repertoires. Cognition and Emotion 19(3), 313-332.

Gibson, D. \& Callister, R. 2010. Anger in organizations: Review and integration. Journal of Management 36 (1), 66-93.

Horila, T. \& Valo, M. 2016. Yhteinen vuorovaikutusosaaminen tiimissä. Prologi: puheviestinnän vuosikirja, 46-58.

Juholin, E. 2013. Communicare - Kasva viestinnän ammattilaiseksi. Helsinki, MIF.

Kessler, S., Buursema, K., Rodopman, P. \& Spector, P. 2013. Leadership, interpersonal conflict, and counterproductive work behavior: An examination of the stressor-strain process. Negotiation and Conflict Management Research 6 (3), 180-190.

Kesti M. \& Syväjärvi A. 2012. Human resource development function to both organizational performance and quality of working life. Journal of Global Business Review GBR 2 (1), 135-141.

Kolari, P. 2010. Tunneälyjohtaminen asiantuntijaorganisaation muutoksessa. Tampereen yliopisto. Väitöskirja. Acta Universitatis Tamperensis 1510.

Kruger, K. \& Brodbeck, F. 2014. Corporate communication and worker perceptions of conflict management and justice. Negotiation and Conflict Management Research 7 (4), 265-281.

Laajalahti, A. 2016. Kriisiviestinnästä kriisivuorovaikutukseen: Puheviestinnän näkökulmia kriiseissä ja kriiseistä viestimiseen. Prologi: puheviestinnän vuosikirja, 76-82.

Lappalainen, P. 2015. Työyhteisötaidot - esimiehiin ja alaisiin kohdistuvat osaamisvaatimukset. Lappeenranta University of Technology. Tuotantotalouden tiedekunta. Raportit ja selvitykset 47.

Matilainen, K. 2014. Koettu palveleva johtajuus, työn imu ja työuupumus: pitkittäistutkimus. Jyväskylän yliopisto. Psykologian pro gradu -työ.

Okhuysen, G., Lepak, D., Ashcraft, K., Labianca, G., Smith, V. \& Steensma, H. 2013. Theories of work and working today: Introduction to special topic forum. Academy of Management Review 38 (4), 491-502.

Pehrman, T. 2011. Paremmin puhumalla: restorativiinen sovittelu työyhteisössä. Lapin yliopisto. Kasvatustieteen väitöskirja.
Pehrman, T. \& Poikela, E. 2015. Työyhteisösovittelu - keino ratkoa konflikteja työpaikoilla. Työelämän tutkimus 13 (2), 127-139.

Pennanen, E. 2015. Hoitohenkilöstön käsitykset työyhteisön vuorovaikutuksen merkityksestä työhyvinvoinnille. Prologi: puheviestinnän vuosikirja, 52-74.

Rainivaara, S. \& Karhunen, S. 2006. Näkökulmia koulun ja työpaikan kiusaamissuhteisiin. Prologi: puheviestinnän vuosikirja, 8-40.

Rothman, J. 2014a. Reflexive pedagogy: Teaching and learning in peace and conflict studies. Conflict Resolution Quarterly 32 (2), 109-128.

Rothman, J. 2014b. The reflexive mediator. Negotiation Journal 30 (4), 441-453.

Rouhiainen, M. 2005. Johtamisviestintä viestintäosaamisen näkökulma johtamiseen. Prologi: puheviestinnän vuosikirja, 32-46.

Vanhala, S. 2014. Hyvinvointia ja tuloksellisuutta hyvällä henkilöstöjohtamisella (HYÖTY). TSR:n hankenumero 110319. Aalto-yliopiston kauppakorkeakoulu ja Työterveyslaitos.

Wall, J. \& Kressler, K. 2012. Research on mediator style: A summary and some research suggestions. Negotiation and Conflict Management Research 5 (4), 403-421. 